UDK 81-116.6:78.01

Bojan Bujić

Oxford University

Univerza v Oxfordu

\title{
A Sacred Bridge or an Unsteady Pontoon? - Some Communication Problems Between Philosophers and Musicians
}

\author{
Sveti most ali nestabilni ponton? - \\ Nekaj komunikacijskih težav \\ med filozofi in glasbeniki
}

Ključne besede: filozofija duha, filozofija jezika, lingvistika, estetika glasbe, narativnost

\section{IZVLEČEK}

Filozofski pogledi na glasbo, ki temeljijo na predpostavki, da je glasba oblika jezika, se srečujejo s težavami. Nekateri aspekti glasbe sicer tendirajo $\mathrm{k}$ jeziku podobnim strukturam, medtem ko se jim drugi umikajo. Če se držimo zgolj jezikovnega modela, potem filozofske teorije prevzemajo določevalni karakter, $\mathrm{z}$ namenom a priornega določevanja, katera glasba ima pomen (zato tudi vrednost) in katera ne. Ta problem je še posebno akuten $\mathrm{v}$ anglosaksonski tradiciji analitične filozofije.
Keywords: Philosophy of mind, philosophy of language, linguistics, aesthetics of music, narrativity

ABSTRACT

Philosophical discussion of music based on the principle that music is a form of language, encounters difficulties. Some aspects of music do tend towards language-like structures, while others pull away from them. If only the language model is upheld, then philosophical theories assume a prescriptive character, aiming to establish in an a priori manner which music has meaning (hence value) and which not. This problem is particularly acute in the Anglo-American tradition of anaytical philosophy. 
[I]f melodies are structures, then the following answer to the question "What is necessary for hearing a sequence of sounds as a melody?" suggests itself: to hear a sequence of sounds as a melody (that is, to hear a melody in them) one has to hear that they exemplify a certain structure - in particular, one must hear that they exemplify a structure the defining relations of which concern only relative pitch, relative duration and order. ${ }^{1}$

The philosophy of music is alive and well, as witness the quotation which may serve as a starting point for exploring - yet again - the old issue of what happens when philosophers talk about music. In the past, and in particular in the distant past, when the Greeks established the foundations of philosophical discourse about music, the relationship of the philosophical discussion and the object of that discussion was a straightforward one. True, we are not even sure what was meant by the word "music" (a lot of scholarly ink has been used in various attempts to determine what the Greeks understood by that term), but at least by our modern standards their works had a few well-defined themes. These were grouped round the discussion of the nature of tuning and of the mathematical foundations of scales and concords; this discussion then led first to the speculation about the cosmic origin of these phenomena and then to the investigation of how all these elements might affect the human soul. In a lot of detail the philosophers customarily took things for granted, since it was not easy to determine empirically all the constituent elements of the discussion. A relatively simple technology was needed in order to establish the mathematical relationship of the length of the vibrating strings to the resulting variation in sound and this single fact may have been a source of encouragement to depart further and deeper into the subject, in the hope that the rest would be equally straightforward. Of course, it was not. A great deal of faith was needed to accept the existence of cosmic harmony, and although this faith was not lacking in Plato's and Aristotle's times, by Pliny's time sceptical voices were being heard. The very belief in the ethical properties of music was questioned from time to time, and even when it was not, again in Plato's and Aristotle's time, it is interesting to note that the standard of proof, usually fairly high in matters of the philosophy of mind and in logic, was not of the same level when it came to music. Matters of the ethical content and the link between musical modes and types of human behaviour were mostly taken on trust and it was enough to invoke the authority of the shadowy Damon and then take it from there.

Even after this cursory survey of the Classical speculation about music, it becomes clear that, although the subject was well defined, the ways of proceeding with the discussion were by no means clear. At least, it was clear who held the upper hand in the discussion: the philosophers took it upon themselves to be the theorists of music as well, while those who pursued music in ways other than theoretical were denied their voice, or had not yet found it and perhaps did not even know that in their vicinity there were those who solemnly discussed the foundations of their art, while despising all that motley crowd of musical practitioners. The march of centuries has, of course, changed all that and the musicians, once only the practitioners, began to evolve into more complex creatures. Thinking about music ceased to be the preserve of philosophers and both the medieval and the renaissance music theorists, while not thinking of themselves as philosophers, took over a lot of what in the Ancient world was considered to have belonged to the philosophers. The Enlightenment philosophers embraced music with a renewed enthusiasm taking it as a territory where some of their ideas about metaphysics - and of course aesthetics - could be tested. This process required a language and a terminology which suited the philosophers' purpose without being too firmly tied to the increasingly dedicated terminology

\footnotetext{
1 Rafael De Clerq, "Melody and Metaphorical Movement", British Journal of Aesthetics, vol. 47 (2007), p. 167.
} 
of music theory. It is in the former sphere, and not in the latter, that we also find the vocabulary of the emerging discipline of music criticism. As both the philosophers and the critics came to prominence during the early phase of Romanticism, especially of its German branch, the vocabulary tended to reflect the current Romantic concerns. Discourse about music was in need of useful concepts and the Romantic preoccupations with "interiority" ("Innerlichkeit"), the "transcendental" and "deep", became favoured amongst the critics and philosophers alike. In our own time, Peter Kivy, as if reconfirming that the roots of his, otherwise modern philosophy of music, are firmly in the eighteenth century, came up with the concept of "profundity", as if wishing to swim against the current of other schools of modern philosophy, those which seem to derive their vocabulary and mode of discourse from linguistic theory and the philosophy of language. ${ }^{2}$

That language and music are somehow connected has been a long-established and widely held belief - it is difficult to use a more specific term than "belief", since here we have an assertion which is difficult to refute, yet an assertion which cannot be strengthened by an incontrovertible historical proof: we believe it to be so, indeed we know it to be so and that is where it stops. The links between music and language were richly explored by the Italian Humanists throughout the sixteenth century, and in a manner different from the eighteenth-century leading figures of the Enlightenment. The latter were fascinated by the primeval links between the voice and the emotion, while the former, on the whole uninterested in anthropological matters, turned their attention to language as a system of formal rules, mainly as regards the rhetoric, and then tried to deduce how a composer might use these structural elements in order to achieve an ideal blend of the poetic substance and the musical garb in which this substance appears clad. The relationship of music and language has been a changeable one, and, as much as we are able to sense their interdependence, we could observe a reverse process, namely that of music wrestling itself away from language and aspiring to an autonomy. John Neubauer saw this as a process of music's "emancipation" and described it in a brilliant study which, victim to the ever-changing modish currents in academic music criticism, has remained unjustly neglected. ${ }^{3}$ On the surface, the process is rather clear and eventually leads to the nineteenth-century schism which divided the adherents of the belief in the purity of "absolute" music and those who advocated a narrative programme as the main aim of a composition. Philosphically speaking, this is an epistemological problem and as such not subject to a historical, evolutionary process but rather an indication of differing modes of thought. However, Nietzsche gave this a historical twist, first in the Birth of Tragedy, where he pursued an allegedly evolutionary link from the primeval music to the more advanced use of music in drama, though essentially he avoided taking sides too strongly, keen as he was, to retain his belief in the freedom of the Dyonisian spirit. Later, in Human, all too Human, he offered a lucid as well as a succinct observation that music does not intrinsically possess narrative properties - it merely borrows them from poetry:

In itself, no music is profound or significant, it does not speak of the 'will' or of the 'thing in itself'; the intellect could suppose such a thing only in an age which had conquered for musical symbolism the entire compass of the inner life. It was the intellect itself which first introduced this significance into sounds: $[\ldots]^{4}$

This is an important observation since in a short span of a couple of sentences it accomplishes much: it warns us not to project properties into music first and then behave as if

2 See among other of this works, P. Kivy, Music Alone. Philosophical Reflections on the Purely Musical Experience, Cornell University Press, Ithaca and London, 1990.

3 John Neubauer, The Emancipation of Music from Language: Departure from Mimesis in Eighteenth-Century Aesthetics, Yale University Press, New Haven, 1986.

Friedrich Nietzsche, Human, all too Human, tr. R. J. Hollingdale, Cambridge University Press, Cambridge, 1986, Vol. I, section 215, p. 99. 
they were there in the first place - epistemology and logic are brought together in a masterful manner. The problem is that the above quotation is preceded by Nietzsche's departure into an evolutionary, causal mode of thinking whereby the so-called "absolute music" is seen as "a primitive stage", so that "[m]en who have remained behind in the evolution of music can understand in a purely formalistic way the same piece of music as the more advanced understand wholly symbolically." Nietzsche was uncharacteristically slack in his judgement, since it by no means follows that, if music is not readily disclosing a symbolic content, it is understood formalistically. If anything, this had been refuted by Hanslick several decades before Nietzsche, but the trouble was that in Nietzsche's mind Hanslick was probably classed as a "formalist" anyway, and he would have been prejudiced against the Viennese critic even after his repudiation of Wagner. Nietzsche exposed himself here to a charge of inconsistency: if the symbolic content was deposited into music in the first place, this was done, presumably, at a very eary stage in man's development, yet the "formalisitic" mode of reception suggests an even older, Apollonian mode, a degree of critical and receptive sophistication, an involvement of reason, none of which should have been there, since such an early stage should have been, in Nietzsche's terms, a Dyonisian one, lacking any formal sense. A seemingly lucid observation about the manner in which language and thought had imprinted themselves on music turns out to contain a contradiction and introduces a difficulty which then continues to plague the philosophy of music.

More recently, Diana Raffman drew attention to the link between the study of music and the study of language: "The idea that music and language might share a distant ancestry has recently been fuelled by the musical application of techniques borrowed from standard Chomskian linguistics." She could, of course, have added that an older theory of linguistics, namely the Saussurean one, provided an inspiration for Jean-Jacques Nattiez's semiological exploration of music. ${ }^{7}$ The concept of language as explored by philosophers of music and music ciritics is in any case a twofold one: (a) language as a means of transmitting information, but without discussing its structure (Nietzsche, Adorno, recent narrativists), and (b) language as structure (semiologists, analytical philosophers). It is interesting to note that Raffman says "might share a distant ancestry" thereby at least acknowledging the difficulty of providing a clear proof that this really is so. Hers is an admirable study which injects much-needed scepticism towards the over-confident attitude in critical writings which explore musical meaning in a philosophical manner. Therefore it is not intended as putting a slight on her effort if we use a tongue-in-cheek remark that, if music and language might share a distant ancestry, then crocodiles and sparrows certainly do share a distant ancestry, yet they not only are now very different animals but in symbolic and associative terms we definitely take them to be different. At this point it is useful to recall Wittgenstein's often quoted duck-rabbit image, designed to be seen as a head of either one or the other animal, depending on our perceptual intentions. Linguistic philosophers tend to use it as a paradigm in a variety of cases, but it must be borne in mind that it works only because the two images share an inherent similarity. But then, we can also attempt to relate a simple outline of a house, as in a child's drawing, to an outline of a motor-car or a bicycle. Indeed, an inquisitive and inventive child might try to do just that if encouraged. We know that rabbit and duck are two natural shapes and we can see a duck's head by reinterpreting the image of rabbit's long ears as the components of a duck's bill. The conditions under which this change occurs are fairly well defined and the imagination has to work up to a certain point for the transformation to take place in our consciousness. But, as human beings, we can also exercise

ibid.

Diana Raffman, Language, Music, and Mind, MIT Press, Cambridge, Mass. and London, 1993, p. 15.

Jean-Jacques Nattiez, Fondements d'une sémiologie de la musique, Union générale d'éditeurs, Paris, 1975. English version: Music and Discourse: Toward a Semiology of Music, tr. Carolyn Abbate, Princeton University Press, Princeton, 1990 
our imagination further, and relate objects such as a house and a motor-car. True, a little more effort is needed: we perhaps need to invert one of the images, adjust some of the components, indulge in some doodling - and the result will follow. It may even delight and surprise us as an exercise of imagination, just as we may derive some curious satisfaction in observing the ingenious absurdities of Escher's images - we know that they cannot stand as three-dimensional structures in nature, but this does not prevent us from experiencing enjoyment as we observe them.

We go back to the relationship of music and language. The "distant ancestry" must also include the possibility of a gradual divergence and, indeed, music history is one long continuum of phases in which both the convergence and the divergence are at play - they are two forces pulling in opposite directions, but in so doing they do not act destructively. For the sake of argument, let us take it that tonal music is closer to the grammatical rules of language and to the duck-rabbit image, while music in which tonal relationships are unclear (early music) or have become intentionally obscured (twentieth-century music), has more in common with the housecar analogy and Escher's drawings. It is becoming rather worryingly clear that there is a tendency in the philosophy of music to consider the first grouping as somehow natural, meaningful, and worthy of philosophical investigation, while declaring the second grouping as at best less interesting and at worst illegitimate. This is seriously at variance with the well-recognized need that if a philosophical theory is to have validity, it ought to apply to as wide a spectrum of categories as possible and not simply pick and choose.

The privileging of tonal music is a theme which runs through a significant portion of linguistic philosophy and the philosophy of music, particularly in the English-speaking world. It is dependant on the belief that context-generated logic of tonal music offers the recipient a chance to equate expectations formed in the language sphere with those which arise in contact with a piece of music. This is, of course, true, but if, and only if, we are determined to feel a sense of security in receiving some information, as when reading the sentence: "The bus to Atlantis will depart __ bay 4". Imagine that our view of the notice is partly obscured or the notice is defaced, yet we are fairly certain that the empty space contains the word "from". It is this type of language situation which has become the touch-stone in the cognitive psychology of music: given a sequence of notes in a tonal melody it is possible to guess the continuation, while the continuation becomes less and less predictable the more elaborate and chromatic the melody becomes. Hence, the difficult and complex melodies mean less, or nothing, and the argument is transferred from everyday "usefullness" to the sphere of artistic imagination, which trivializes the point.

Of course, in the aesthetic sphere there are many examples of the form and context producing predictability, or determining the exact placement of the units of sense, as in the following excerpt from Alfred Lord Tennyson's "In Memoriam" (poem 5, lines 1-8):

I sometimes hold it half a sin

To put in words the grief I feel;

For words, like Nature, half reveal

And half conceal the Soul within.

But, for the unquiet heart and brain,

A use in measured language lies;

The sad mechanic exercise,

Like dull narcotics, numbing pain.

The italicized words (not by Tennyson!) are definitely related. But if someone has incorrectly remembered lines 1-4 it would be quite possible to put pain instead of grief in line 2 if only these 
four lines were at stake. However, once we go beyond line 4, pain at the end of line 8 would emerge as stylistically weak and the whole context wrong; at the same time, it is unlikely that anyone would misremember lines 5-8 to the extent of not sensing that pain is the right word at the end. The context and the formal properties act as safeguards - just as in tonal music certain constraints act as guides. This is poetry - good poetry of a certain stylistic kind and of its time. Does the following fragment then fail as poetry?

la roulotte au bord du clou

et cadavre dans le panier

et chevaux de labours dans le fer à cheval

je rêve la tête sur la pointe de mon couteau

le Pérou

Of course, we don't quite know where we are going, but only in the sense that at first the poem seems odd - yet, the more we hear or read it, the more we gain, and not just in terms of the tension produced by the sequence of unrelated objects. The poetry becomes a phantasy in sound: there are the phonetic links between 'roulotte' and 'clou', 'chevaux' and 'cheval' and then the overarching pair 'clou' - 'Pérou' which, in addition, acts as a component of form. In terms of the informational content 'le Pérou' does, indeed, make little sense, but the context makes us realize that it is not out of place since the melody of the poetry justifies it. Without disparaging Tennyson, we may assert that his "In Memoriam" is closer to the notice at a bus station while René Char's "l'artisanat furieux" from Le marteau sans maître is closer to Escher's drawings. But this is only because Tennyson tells us a story of a past event, while Char constructs a story from scratch. Tennyson is helpful at first, though we would be deluding ourselves if we thought that the rhythm of the verse and the predictable rhyming words help us to find out what it was that motivated Tennyson to write the poem - the content of the lines has to do with grief and loss, though if we only read Tennyson's poem and not his biography we shall never find out the identity of the friend whose death he laments. So, he is still not as useful as the bus station notice and, aesthetically, and not pragmatically speaking, he is still closer to Char than to the everyday world of trivial notices.

I feel that somehow the cognitive psychologists of music and some linguistic philosophers fail to see the importance of these distinctions. Some thirty years after the first performance of Boulez's Le marteau sans maître (1955), his music and his setting of Char's poetry stil provoke critical controversy, not unlike Wagner's music in its day, not to mention Schoenberg's. Fred Lerdahl, a co-author of the influential A Generative Theory of Tonal Music in another study raised an objection that Boulez's creative, i.e. formal, constructive processes cannot be "read" from the finished piece - and as in this particular case the tenets of Chomskian linguistics cannot be applied, he took this as sufficient reason for a negative judgement not only of the work but of the whole of Boulez's compositional endeavour. ${ }^{9}$ Roger Scruton echoed Lerdahl when he argued that:

[we] are amazed and exilerated by Beethoven's formal achievements - like the first movement of the Eroica - because the material which they organize lives separately in us. Le Marteau sans maître gives no comparable experience, since it contains no recognizable material - no units of significance that can live outside the work that produces them. ${ }^{10}$

\footnotetext{
Fred Lerdahl and Ray Jackendoff, A Generative Theory of Tonal Music, MIT Press, Cambridge, Mass. and London, 1983.

F. Lerdahl, "Cognitive Constraints on Compositional Systems", in John Sloboda (ed.), Generative Processes in Music, Oxford University Press, Oxford, 1988

10 Roger Scruton, The Aesthetics of Music, Clarendon Press, Oxford, 1997, p. 455.
} 
This is a rather general statement and, as I mentioned earlier, if it is to be accepted as philosophically universally valid, then it ought to apply to a variety of historical situations. Boulez's composition may come in useful as an object of criticism, because of its unusual, novel language, but to claim that it "contains no recognizable material" is a rather arbitrary statement. First, it generates its own context, just as Char's poetry generates its context. Then, Scruton seems to regard that there should be only one listening strategy, the one applicable to the tonal music of the 18th-19th centuries, in which tonal directedness and the antecedent-consequent structure of musical periods provide the backbone. Le marteau relies on the concentration on the moment as well as on the impact of the entire large structure - indeed it relies on both at once, showing that a work of music, which on the whole does not follow the rules of flow demanded of discursive language, can generate its own dialectical situations. It seems that Scruton's requirement of recognizable material would encounter problems at the other end of the historical spectrum too. Perotinus's "Sederunt principes" is undoubtedly much easier on the ear than Boulez. Yet, in Scruton's terms this too would fail the test. True, its notation was based on modal principles derived from prosody, hence ultimately from language, but the human imagination has produced such transformations of this link that the rhythmic profile of the music has wrestled itself away from language. The piece sets a text to music - a fragment of liturgical prose text, the individual syllables of which became so elongated in melizmas that they cease to have any discursive value - they transmit no information. The final impact is a dialectical interplay of short phrases tending towards points of consonant congruence and of an almost obsessive, mesmerizing continuum of sound. The structural components of Perotinus and Boulez are not a million miles apart. Not unlike Perotinus's composition, a complex isorhythmic motet by Vitry could not easily satisfy either Lerdahl's or Scruton's conditions: in Lerdahl's terms the structural process cannot be read from the score and in Scruton's terms it would be difficult to find the "recognizable material", unless it be some deep awareness of mathematical proportions, which, in rational terms, Scruton would quite rightly find difficult to endorse. Does this mean that all compositions which belong to the phase preceding functional tonality and the standard classical forms of expectation and closure belong to some musical darkness in which the music's true being had not been realized? I doubt that any analytically-trained philosopher would support this hopelessly deterministic view.

Diana Raffman seems to have offered a way out by stating that "the experienced listener a musical analogue to Chomsky's ideal speaker-hearer - is one familiar with an idiom but not necessarily schooled in its theory." 11 This goes a certain way towards resolving the difficulty in which Scruton had placed himself: the required experience is not the one which "lives separately in us" but an experience which is a result of an ability to make associations with other pieces of music. A dialectics thus may be established between a piece of very old music, such as a straightforward troubadour melody, which pulls towards language, and a contemporary to it Notre Dame composition which pulls away from language. Both belong to a certain historical type of the sound-world, but the listening strategies slightly differ in their cases. Similarly, Boulez's Le marteau and, say, Stravinsky's Symphonies of Wind Instruments share some elements (a tendency to concentrate on a small musical detail) though the latter composer helps us by repeating while the former avoids repetition. But the general familiarity with the requirements of the idiom, as suggested by Raffman, would help with illuminating Boulez's piece in such a way that we begin to recognize some tenuous links with the musical past - some quasi-tonal suggestions would become obvious, timbral transformations would provide links with Stravinsky and Schoenberg. History is thus inevitably contained in a work of art, and the only difference

11 D. Raffman, ibid. p. 15. 
is that there is less history in Perotinus (not enough of previous music to which it relates) and more history in Boulez and Stravinsky. It is therefore unhelpful to remove a work from the historical sphere, as the cognitive psychologists want to do, or to evaulate historical contexts selectively, as Scruton seems to have done.

Rather than remaining the intellectually voiceless composers of many centuries ago, composers have with time gained a philosophical insight into their own art and a voice with which to argue it - they no longer have to defer to the musically-inclined philosophers, as used to be the case. Arnold Schoenberg wrote in 1934: "An idea in music consists principally in the relation of tones to one another. But every relation that has been used too often, no matter how extensively modified, must finally be regarded as exhausted; it ceases to have power to convey a thought worthy of expression." ${ }^{2}$ Someone may say that, of course, Schoenberg had an axe to grind, were it not for the fact that here he came very close to what Eduard Hanslick had written exactly eighty years before him. Schoenberg simply echoed an already existing lucid observation that in certain respects musical material contains an inbuilt obsolescence: its meaning, unlike the meaning generated by grammatical constructions in language, suffers through re-use. It is for this reason that any philosophical theory of music which constantly privileges language and disregards specifical musical processes is likely to remain unconvincing.

Rafael De Clerq's conditions for hearing a sequence of sounds as a melody has been quoted at the beginning of this paper as an example of a continuing interest the philosophers show in music as an area for testing general theories of meaning. The quoted excerpt forms a part of a long and sophisticated argument, in the course of which De Clerq also considers various views relating to the notion of "movement" in a melody. The problem arises when one stops to think what impact this argument may have on a musical as opposed to a philosophical reader. The former will decide, no doubt with some regret, that what is being discussed is so general as to be useless in any attempt to conceptualize aspects of musical structure. De Clerq seems to admit as much when he refers to Scruton's view of a particular view of musical organization as being "a more general philosophical problem, and of little interest to the philosophy of music." ${ }^{3}$ We are thus faced with a situation that, on the one hand, when philosophers and cognitive psychologists of music decide to engage with music on the level of complex structural factors, they tend to become tendentiously prescriptive and, on the other hand, when they wish to be more philosophically general, their discussion becomes so diluted as to be unhelpful. This puts a question mark over the widespread belief that somehow music and philosophy inspire each other, and do so on a very deep and significant level. This interaction certainly took place during certain periods of European civilization, but, from the perspective of the modern analytical philosophy such links are seen as too metaphysical and fanciful. Yet, the anaytical philosophers have themselves shown some serious weaknesses in their arguments about music: the much celebrated sacred bridge connecting music and philosophy turns out to be a shaky and unsteady pontoon.

\section{Povzetek}

Dolga zgodovina zanimanja, ki so ga kazali filozofi do glasbe kot področja, na katerem je mogoče preveriti epistemološke, etične in estetske teorije, ni brez svojih težav. Že v antičnem obdobju se je pokazalo, da je

12 Arnold Schoenberg, "Problems of Harmony". In its original form this was a lecture which Schoenberg delivered to the Prussian Academy in Berlin in 1927; the essay was then published in English in 1934. Here quoted from: A. Schoenberg Style, and Idea, ed. L Stein, Faber and Faber, London, 1975, p. 269.

13 De Clerq, ibid, p. 156. 
bil standard filozofskega dokazovanja (ob obravnavi glasbe) nižji kot tedaj, ko je šlo za druge filozofske dialoge. V novejšem času so nesporazumi med filozofi in glasbeniki ponovno izraženi, posebej znotraj anglo-ameriške analitične filozofije. Izhajajoč iz predpostavke, da je glasba jezikovni in komunikacijski sistem ter da je mogoče njeno strukturo zvesti na lingvistične postulate, posebej tiste, ki jih postavlja Noam Chomski, filozofi pogosto izražajo skepso do vrednosti atonalne glasbe, kjer teh postulatov ni mogoče uporabiti brez težav. Vendar, če izhajamo iz predpostavke analitične filozofije, da naj bi mišljenja uporabili čim bolj univerzalno v mnoštvu situacij, se kaže nelogičnost takšnega analitičnega pristopa h glasbi, saj so zanemarjene neke posebnosti glasbe kot strukturnega sistema, ki se razlikuje od osnovnih postulatov, izvedenih iz filozofije jezika. 